\title{
2021 Handbook of Florida Water Regulation: Notes and Glossary ${ }^{1}$
}

\author{
Michael T. Olexa, Tatiana Borisova, and Jana Caracciolo
}

\section{Preface}

This handbook is designed to provide an accurate, current, and authoritative summary of the principal federal and state (Florida) laws that directly or indirectly relate to agriculture. This handbook provides a basic overview of the many rights and responsibilities that farmers and farmland owners have under both federal and state laws as well as the appropriate contact information to obtain more detailed information. However, the reader should be aware that because the laws, administrative rulings, and court decisions on which this handbook is based are subject to constant revision, portions of this publication could become outdated at any time. Several details of cited laws are also left out due to space limitations. This handbook is provided as an educational text for those interested in water use and water resource issues in Florida.

This handbook is distributed with the understanding that the authors are not engaged in rendering legal or other professional advice, and the information contained herein should not be regarded as a substitute for professional advice. This handbook is not all inclusive in providing information to achieve compliance with the federal and state laws and regulations governing water protection. For these reasons, the use of these materials by any person constitutes an agreement to hold harmless the authors, the UF/IFAS Center for Agricultural and Natural Resource Law, and UF/IFAS Extension for any liability claims, damages, or expenses that may be incurred by any person as a result of reference to or reliance on the information contained in this handbook. Note: UF/IFAS is the acronym for University of Florida, Institute of Food and Agricultural Sciences.

\section{Notes}

The Environmental Information Service Center can connect anyone to Region 4 or assist with agency-related questions Monday through Friday, from 8:00 AM to 5:00 PM at (404) 562-9900 or (800) 241-1754.

\section{Glossary}

AD VALOREM TAX - tax imposed on the value of property

APPURTENANT - any artificial improvement to a dam that might affect the safety of such dam, or when employed might affect the holding capacity of such dam or reservoir, or impoundment created by such dam

ARRANGERS-anyone involved in arranging for the transportation of hazardous waste, such as a middle man who contacted the transporter to ship the hazardous waste, etc.

1. This document is FE617, one of a series of the Food and Resource Economics Department, UF/IFAS Extension. Original publication date October 1998. Revised June 2017 and April 2021. Visit the EDIS website at https://edis.ifas.ufl.edu for the currently supported version of this publication.

2. Michael T. Olexa, professor, Food and Resource Economics Department, and director, UF/IFAS Center for Agricultural and Natural Resource Law; Tatiana Borisova, associate professor, Food and Resource Economics Department; and Jana Caracciolo, student, Levin College of Law; UF/IFAS Extension, Gainesville, FL 32611.

The Institute of Food and Agricultural Sciences (IFAS) is an Equal Opportunity Institution authorized to provide research, educational information and other services

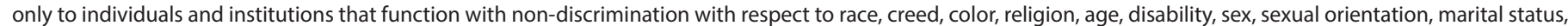

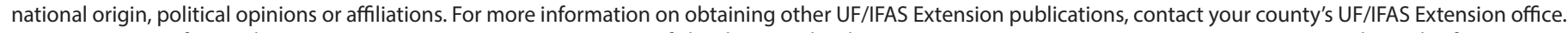
U.S. Department of Agriculture, UF/IFAS Extension Service, University of Florida, IFAS, Florida A \& M University Cooperative Extension Program, and Boards of County Commissioners Cooperating. Nick T. Place, dean for UF/IFAS Extension. 
AQUIFER — vast underground, porous rocks that hold water and allow water to move through the holes within the rock (https://www.sjrwmd.com/water-supply/aquifer/)

BASIN BOARDS - water management board with authority to develop water use plans

BEST MANAGEMENT PRACTICES (BMP) - management and cultural practices designed to efficiently use and conserve the land or improve water quality in agricultural and urban discharges

BLACKWATER — residential wastewater from toilets or kitchens

BROWNFIELD SITE - real property, the expansion, redevelopment, or reuse of which may be complicated by the presence or potential presence of a hazardous substance, pollutant, or contaminant

BYPRODUCT MATERIAL — any radioactive material (except special nuclear material) yielded in or made radioactive by exposure to the radiation incident to the process of producing or using special nuclear material; ....any discrete source of radium-266 that is produced, extracted, or converted after extraction... for use for a commercial, medical, or research activity; or any material that has been made radioactive by use of a particle accelerator and is produced, extracted, or converted after extraction... for use for a commercial, medical, or research activity (United States Nuclear Regulatory Commission, http://www.nrc. gov/materials/byproduct-mat.html)

CARCINOGEN — an agent that has been scientifically proven to cause cancer

CLOSED SYSTEM - a system that exchanges neither matter nor energy with its surroundings

COMMON LAW-law determined by courts or custom, in contrast with statutory law or legislatively made law

CONTAMINANT—a measurable amount of a foreign substance

DE MICROMIS—an exemption from CERCLA under which arrangers or transporters of a hazardous waste substance are not liable for cleanup costs as long as they can demonstrate that the amount of the hazardous substances they arranged for the transportation of or transported was less than 110 gallons of liquid materials or less than 200 pounds of solid materials and all or part of the disposal, treatment, or transport occurred before April 1, 2001

DEWATERING - the temporary removal of water by well pumps from subsurface formations for mining, quarrying, or construction purposes

EFFLUENT_liquid discharge from point source; sometimes refers to liquid that comes from a treatment plant after completion of the treatment process

EXTREMELY HAZARDOUS SUBSTANCE-any substance listed as an extremely hazardous substance by the EPA under EPCRA

FEDERAL CAUSE OF ACTION-a group of facts giving rise to one or more bases for suing in federal court

FELONY/MISDEMEANOR-felonies are usually punished with high fines and/or prison sentences, while misdemeanors are offenses lower than felonies and punishable by lesser fines and/or shorter prison sentences

GREYWATER/GRAYWATER—residential wastewater (showers, washing machines, etc.)

HAZARDOUS CHEMICAL - any chemical that is a physical hazard or a health hazard and that is listed as a hazardous chemical by EPA under EPCRA

HAZARDOUS WASTE-waste considered a threat to human health or the environment by EPA; does not include petroleum, although some petroleum products are hazardous wastes

INJECTION WELL-[according to EPA, as defined in Title 40, Code of Federal Regulations, Section 144.3], a bored, drilled, or driven shaft whose depth is greater than the largest surface dimension; or a dug hole whose depth is greater than the largest surface dimension; or an improved sinkhole; or a subsurface fluid distribution system into which fluids (any material or substance which flows or moves whether in a semisolid, liquid, sludge, gas, or any other form or state) are emplaced

INJUNCTIVE RELIEF—court order to prohibit someone from doing some specified act or to command someone to undo some wrong or injury (e.g., a restraining order)

JOINT AND SEVERAL LIABILITY-when a wronged party may sue one or more of the offending parties 
either separately or together (responsible together and individually)

LIEN - a claim or charge on property for payment of some debt, obligation, or duty

LIABILITY - the state of being bound or obliged in law to do, pay, or make good on something

LEACHING-process by which nutrient chemicals or contaminants are dissolved and carried away by water or are moved into a lower layer of soil

MITIGATION - a legal process by which a penalty or punishment is reduced or made less severe to make less severe

MINIMUM WATER LEVEL-the level of water below which withdrawals would be harmful to the ecosystem or water resources; set by water management districts

NITROGEN STABILIZER-any substance or mixture of substances intended to prevent or hinder the process of nitrification, denitrification, ammonia volatilization, or urease production through action upon soil bacteria

NEGLIGENCE-failure to use such care as a reasonably prudent and careful person would use under similar circumstances

NEGLIGENCE PER SE- $\mathrm{a}$ form of negligence that results from violation of a statute (e.g., running a red light)

NONPOINT SOURCE—-nondiscernable source of pollution (i.e., agricultural runoff and urban runoff)

PCB - polychlorinated biphenyls, common humanproduced carcinogens; often found in coolants, pesticide extenders, flame retardants, sealants, and adhesives

PESTICIDE—any substance used to regulate, prevent, repel, or destroy any pest or plant

POINT SOURCE—-discernible channel through which wastes are discharged (i.e., pipes, sewers, and channels)

POLLUTANT - a contaminant in water, soil, or air that is present in such a degree that the use of the resource is impaired; includes gasoline or oil, any pesticide, or any ammonia or chlorine compound or derivative
RECLAMATION - process of increasing mined land or other used resource to a higher value by physically changing the land (i.e., wetland reclamation)

SOLID WASTE - trash, sludge, and semi-liquid and gaseous wastes; does not include domestic sewage, irrigation return flow, or pollutants included in NPDES permits

SOURCE MATERIAL-uranium, thorium, or any other material that is determined by the Atomic Energy Commission to be source material; or ores containing one or more of the foregoing materials

SPECIAL NUCLEAR MATERIAL—plutonium, uranium enriched in isotope 233 or in isotope 235 , and any other material that is determined by the Atomic Energy Commission to be special nuclear material, not including source material; or any material enriched by any of the foregoing, but not including source material

STANDING-a party's right to make a legal claim or seek judicial enforcement of a duty or right

STRICT LIABILITY-liability without fault, when one is responsible for all consequences regardless of one's fault

THREATENED/ENDANGERED SPECIES—-species of plants or animals that are threatened with extinction or that are in danger of extinction

TOTAL MAXIMUM DAILY LOADS-the calculation of the maximum amount of a pollutant allowed to enter a waterbody so that the waterbody will meet and continue to meet water quality standards for that particular pollutant. A TMDL determines a pollutant reduction target and allocates load reductions necessary to the source(s) of the pollutant (from https://www.epa.gov/tmdl/ overview-total-maximum-daily-loads-tmdls)

TOXIC CHEMICALS-those chemicals that present unreasonable risk of injury to public health or the environment and are listed as toxic chemicals by EPA under EPCRA

TOXIC SUBSTANCES-substances carrying a risk of producing birth defects, heart disease, emphysema, or other health problems in humans or carrying a risk to injure the environment

VICARIOUS LIABILITY-liability of an employer based on actions of an employee that occurs within the scope of his or her employment 
WETLANDS-lands supporting vegetation suited to a wetland environment and/or covered periodically with water

ZONE OF DISCHARGE-predefined three-dimensional area underground around a source of water going into the ground; usually has more relaxed water quality standards before the water reaches groundwater supply

\section{Acknowledgments}

The authors are indebted to the personnel of both state and federal agencies who provided their time and advice in the preparation of this handbook. We acknowledge Carol Fountain and Susan Gildersleeve at the University of Florida for their assistance in editing this handbook. We also acknowledge funding received for updating this publication from the James S. and Dorothy F. Wershow Agricultural Law Endowment. 